\title{
The Influence of Logical Intelligence of Mathematics and Soft Skills on Students' Learning Outcomes of Introductory Economics Course
}

\author{
Thamrin ${ }^{1}$, Abdul Hasan Saragih ${ }^{1}$, Abdul Muin Sibuea1 \\ ${ }^{1}$ Faculty of Economics, Universitas Negeri Medan, Medan -Indonesia \\ thamrinpit@gmail.com
}

\begin{abstract}
The problem of education is relatively complex because many variables influence it. One of these factors is the characteristics (logical intelligence mathematics) and student Soft Skills. The phenomena that occur in the field, especially in the learning process of the lecturer/teacher, that they do not pay attention to the problems of logical intelligence of mathematics and student soft skills, so that the learning outcomes are not optimal. This study aims to determine the effect of logical intelligence of mathematics and soft skills on learning outcomes in students of introductory economics. This research method is the descriptive expost facto method. The population in this study were all students of the economic education department in Economics Faculty Unimed who were attending the introductory economics as many as 90 people. The data collected was analyzed using linear regression statistics with SPSS for windows. The results of this study indicate that logical intelligence of mathematics and soft skills have a positive and significant effect on student outcomes in the introductory economics course.
\end{abstract}

Keywords : logical intelligence, mathematics, soft skills, learning outcomes

\section{Introduction}

Introduction of economics is one of the primary subjects in economics that should be taken by the students in the economic education graduate program. The introduction of economics course is the essential subject of study with the aim of learning that students are competent in identifying and analyzing the behavior of individual economic actors, explaining the process of equilibrium prices, applying them in daily life both as consumers and producers and analyzing markets.

This introductory economics course is essential for students because these alumni from the study program of economic education will later become professional teachers in economics at the high school/vocational level and teach the knowledge related to introducing this economy to their students. Based on this, the introductory economics course must be truly mastered by students. But the reality shows that student learning outcomes are not satisfactory. Data on the acquisition of student economic learning outcomes shows that only $5.70 \%$ of students get the maximum score (A), $11.42 \%$ get a B score, while those who get a $\mathrm{C}$ score there are $48.57 \%$ and those who do not pass with an E value of 34, 28\% (Source of data for the Final Value of 2014 economic education study program).

From the educational technology point of view, according to the framework of learning theory, the problem of the low quality of learning is the problem of originating from the characteristics of students in the form of intelligence in the form of mathematical logics (Reigeluth, 2003; Miarso, 2004). Furthermore, Sobur (2013) explained that children whose intelligence level is classified as less or lower than the level of the general ability of their age children would experience difficulties in following lessons that are normal for other children. 
For other children, just reading and understanding what is learned is enough, he must read many times to understand.

Another factor that can affect learning outcomes is that soft skills are part of a person's skills that are more about the subtlety or sensitivity of one's feelings towards the environment around them. Soft skills are a person's skills in dealing with others.

Universitas Negeri Medan (Unimed) has determined that there are eleven elements of soft skills integrated with lectures, among others: honesty, respect, responsibility, fairness, caring, citizenship, tolerance, toughness, dignity, intelligence, religion. Logical intelligence of mathematics and soft skills are thought to influence the learning outcomes of introducing economic students in economic education graduate programs.

\section{Theoritical Framework}

Becker and Watts (1996) and Fry, Ketteridge and Marshall (2008) explain that learning economics is increasingly based on analytical models that require a high level of mathematical understanding, where the past is more discursive and text-based. Like other disciplines that need good mathematical skills.

The introductory economics course requires mathematics logical intelligence in students because introductory economics courses are not only related to the concept of mathematically calculating but the ability to analyze phenomena occurring in the economy which of course requires logic to an alyze the phenomenon and then try to solve problems according to phenomenon. The intelligence of mathematical logic is needed as a basis for studying introductory economics courses.

According to Lwin et al., (2008), mathematics logical intelligence is the ability to handle numbers, calculations, patterns, logical and scientific thinking. Further explained that the relationship between mathematics and logic is that both strictly adhere to the fundamental law. The lack of mathematical logic results in a large number of individual and cultural problems.

Furthermore, Armstrong (2013) explains that mathematics logical intelligence is the ability to use numbers. This intelligence includes sensitivity to logical patterns and relationships, statements and arguments (if-then, causation), functions, and other related abstractions.

The types of processes used in logical-mathematical intelligence services include categorization, classification, inference, generalization, calculation, and hypothesis testing. Based on the explanation above, it can be seen that mathematics logical intelligence gives a person the capacity to use numbers effectively, sensitive to logical patterns, statement relations, and causal conditions. In this study students who have mathematics logical intelligence will be able to use numbers effectively, be sensitive to logical patterns, statement relationships, and causal conditions that are useful for problem-solving in learning Introduction to economics.

Another factor that is no less important influences the learning outcomes of introducing economics is the Soft skills of the students concerned. Ngang, Hashim and Yunus (2015) explained that soft skills combine aspects of general skills which include non-academic skills such as communicative, critical thinking and problem solving, teamwork, learning, and information throughout life, entrepreneurship, professional ethics and morals, and leadership. 
Cimatti (2016) further explained that Softskills predict success in life. Cimatti (2016) identifies causal correlations between Soft skills and personal and professional achievements of a person.

The results of the Mujiani's study (2016) explain that there is an influence of high and low logical intelligence of mathematics on learning outcomes. From the whole opinion above, it becomes a strong theoretical foundation to build the hypothesis of this research that there is the influence of mathematics logical intelligence and soft skills on the introductory learning outcomes of the economy.

In this study, the elements of soft skills refer to the book on the development of Unimed academic culture where there are eleven soft skill elements which integrated into the learning process.

\section{Research Method}

This research using ex-post facto research method. The study was conducted on students who had participated in introductory economic lectures. The population in this study were all economic education students who had just joined the introductory economics lectures as many as 90 students. The sampling technique used is total sampling. Data was collected through a questionnaire about soft skills and tests to measure students' intelligence of mathematical logics.

The data were analyzed using multiple linear regression statistics with the help of SPSS version 20 application.

\section{Results And Discussion}

Based on the data that has been analyzed, the results of research on mathematics logical intelligence, soft skills and learning outcomes introducing economic students as shown in Table 1 .

Table.1. Logical Intelligence of Mathematics, Soft Skills and Learning Outcomes Introduction to Economics

\begin{tabular}{|l|c|c|c|}
\hline & Mean & $\begin{array}{c}\text { Std. } \\
\text { Deviation }\end{array}$ & $\mathrm{N}$ \\
\hline Learning outcome & 73.92 & 9.51 & 90 \\
$\begin{array}{l}\text { Mathematics Logical } \\
\text { Intelegence }\end{array}$ & 72.93 & 11.26 & 90 \\
Softskills & 3.39 & 26128 & 90 \\
\hline
\end{tabular}

Refers to Table.1, it can be seen that logical intelligence of mathematics and soft skills are in the good category (average score of 73.92). The soft skills category is as shown in Table.2. 
Table 2. Category of Mathematics Logical Intelegence in Table.3.

\begin{tabular}{|c|c|c|}
\hline No & Interval & Category \\
\hline 1 & $80-92$ & Very Good \\
\hline 2 & $68-80$ & Good \\
\hline 3 & $56-68$ & Sufficient \\
\hline 4 & $44-56$ & Poor \\
\hline
\end{tabular}

Furthermore, the categories of soft skills for economic education students can observed

Table 3. Category of Soft Skills

\begin{tabular}{|c|c|c|}
\hline No & Interval & Category \\
\hline 1 & $3,56-3,76$ & Very Good \\
\hline 2 & $3,36-3,55$ & Good \\
\hline 3 & $3,16-3,35$ & Sufficient \\
\hline 4 & $2,96-3,15$ & Poor \\
\hline
\end{tabular}

Based on the soft skills category in Table.3, the Soft skills of students in economic education graduate programs are in a good grade (average score of 3.39). Furthermore, the primary learning outcomes of student economics categorized following to Table 4 below.

Table 4. Category of Learning Result

\begin{tabular}{|l|c|c|}
\hline No & Interval & Category \\
\hline 1 & $86-94,09$ & Very Good \\
\hline 2 & $77,91-85,99$ & Good \\
\hline 3 & $69,82-77,90$ & Sufficient \\
\hline 4 & $61,73-69,81$ & Poor \\
\hline
\end{tabular}

According to the data in Table 4, it can be seen that the learning outcomes of students' in the introduction of economics subject are in a sufficient category (average score of 73.92).

Data collected was analyzed by linear regression statistics. Before examining the data, normality and linearity have been tested, and the data has met the requirements for normality and linearity test.

Furthermore, the results of data processing to see the effect of mathematics logical intelligence and soft skills on learning outcomes can be seen in Table 5 as follow.

Table 5. The Result of Regression Analysis

\begin{tabular}{|l|l|l|c|c|c|}
\hline Model & \multicolumn{2}{|c|}{$\begin{array}{c}\text { Unstandardized } \\
\text { Coefficients }\end{array}$} & $\begin{array}{c}\text { Standardized } \\
\text { Coefficients }\end{array}$ & \multirow{2}{*}{ Sig. } & \\
\cline { 2 - 4 } & \multicolumn{1}{|c|}{$\mathrm{B}$} & Std. Error & Beta & & \\
\hline (Constant) & 13.38 & 13.261 & & 1.009 & .316 \\
KLM & 309 & .080 & .366 & 3.865 & .000 \\
Softskills & 11.18 & 3.447 & .307 & 3.244 & .002 \\
\hline
\end{tabular}

a. Dependent Variable: learning outcome. 
The result shows there is a positive and significant influence of mathematics logical intelligence on student learning outcomes in the introduction of economics subject (sig 0.005 0.05). Likewise, the soft skills have a positive and significant effect on economic learning outcomes with ( $\operatorname{sig} 0.002 \leq 0.05$ ) which means that student's soft skills positively and significantly influence the learning outcomes of the students. Therefore, mathematics logical intelligence and soft skills affect the learning outcomes as can be seen in the results of data processing in Table 6.

Based on the table, it can be found that the linear regression equation is:

$$
\mathrm{Y}=13.38+0.31 \mathrm{X} 1+11.18 \mathrm{X} 2 .
$$

Which means that the constant 13.38 shows that if mathematics logical intelligence and soft skills are 0 , then the learning outcomes of the student are 13.38. The regression coefficient of mathematics logical intelligence (X1) of 0.31 explains that if students' mathematics logical intelligence increases one unit, then the learning outcomes increase by 0.31 units assuming other independent variables remain. The soft skills regression coefficient 11.18 shows that if a student's soft skills increase by one unit, then the learning outcomes of the student will increase by 11.18 units assuming other independent variables remain. The result of the effect of mathematics logical intelegence and softs kills on learning outcomes can observed in table 6 below.

Table 6. Table of ANOVA

\begin{tabular}{|l|l|c|c|c|c|}
\hline Model & $\begin{array}{l}\text { Sum of } \\
\text { Squares }\end{array}$ & df & $\begin{array}{c}\text { Mean } \\
\text { Square }\end{array}$ & F & Sig. \\
\hline Regression & 1788.355 & 2 & 894.17 & 12.39 & $.000^{\mathrm{b}}$ \\
Residual & 6277.180 & 87 & 72.15 & & \\
Total & 8065.535 & 89 & & & \\
\hline
\end{tabular}

a. Dependent Variable: learning outcomes

b. Predictors: (Constant), Softs kills, Mathematics Logical Intelegence

Based on Table 6, it can be seen that together mathematics logical intelligence and soft skills variables have a positive and significant effect on learning outcomes (sig $0.000<0,05)$.

The results of this study prove that mathematics logical intelligence and soft skills have a positive and significant impact on the learning outcomes of the introduction of economics subject. The introductory learning outcomes of the economy are the culmination of learning activities carried out by students and lecturers.

\section{Conclusions}

In recent years, a large number of studies have established the importance of soft skills in fostering student academic achievement and long-term success. Some educators consider soft skills as a critical instrument for the application of lessons learned in core academic subjects. Educators often frame soft skills development as a complementary instruction in the core academic and school fields praising the "balanced approach" to produce graduates with 
"rigorous content knowledge and the ability to apply that knowledge successfully. Other researchers and educators highlight the direct impact of soft skill development on achievement in core academic subjects. Students who participate in cooperative learning, for example, not only improve teamwork skills but also learn faster and more efficiently, are more likely to stay in their education, and feel more positive about learning than students taught in traditional classroom settings. The findings of this study are in line with Pereira's (2013) and Souza's et al. (2018) research, which explains that students in all programs should emphasize the importance of soft skills in their education experience.

\section{References}

Armstrong, M. A. (2013) Basic topology. Springer Science \& Business Media.

Becker, W. E. and Watts, M. (1996) 'Chalk and Talk: A National Survey on Teaching Undergraduate Economics', American Economic Review, 86(2), pp. 448-453.

Cimatti, B. (2016) 'Definition, Development, Assessment of Soft Skills and Their Role for the Quality of', International Journal on Language, Literature and Culture in Education, 10(1), pp. 97-130. doi: 10.18421/IJQR10.01-05.

Fry, H., Ketteridge, S. and Marshall, S. (2008) A handbook for teaching and learning in higher education: Enhancing academic practice. Routledge.

Lwin, M. et al. (2008) Cara Mengembangkan Berbagai Komponen Kecerdasan. Yogyakarta: Indeks.

Miarso, Y. (2004) Menyemai benih teknologi pendidikan. Jakarta: Kencana.

Mujiani, D. S. (2016) 'Pengaruh Media Pembelajaran dan Kecerdasan Logis Matematis Terhadap Hasil Belajar Matematika Siswa’, Jurnal Pendidikan Dasar, 7(2), pp. 199209.

Ngang, T. K., Hashim, N. H. and Yunus, H. M. (2015) 'Novice Teacher Perceptions of the Soft Skills Needed in Today's Workplace', Procedia - Social and Behavioral Sciences. Elsevier B.V., 177(July 2014), pp. 284-288. doi: 10.1016/j.sbspro.2015.02.338.

Pereira, O. P. (2013) 'Soft skills: From university to the work environment. Analysis of a survey of graduates in Portugal', Regional and Sectoral Economic Studies, 13(1), pp. $105-118$.

Reigeluth, C. M. (2003) Instructional design theories and models: An overview of their current status. Routledge.

Sobur, A. (2013) Psikologi Umum dalam Lintasan Sejarah. Bandung: Pustaka Setia.

Souza, M. R. d. A. et al. (2018) 'A systematic mapping study on game-related methods for software engineering education', Information and Software Technology. Elsevier B.V., 95, pp. 201-218. doi: 10.1016/j.infsof.2017.09.014. 